\title{
Transforming Growth Factor- $\beta 2$ protects the small intestine during methotrexate treatment in rats possibly by reducing stem cell cycling
}

\author{
B van't Land', HP Meijer', J Frerichs', M Koetsier', D Jager', RL Smeets', L M'Rabet*,', and M Hoijer'
}

'Numico-Research, Department of Condition and Disease Specific Research, Bosrandweg 20, PO Box 6700 CA Wageningen, The Netherlands

\begin{abstract}
During chemo- and radiation therapy, the balance between epithelial cell proliferation, differentiation, and cell death at the villus tip is disrupted by premature death of dividing epithelial cells. This will subsequently lead to the onset of mucosal barrier injury in the whole gastrointestinal tract. Up till now there is no validated method to treat side effects occurring due to therapy. An approach to manage this side effect might be to reversibly arrest growth of epithelial stem cells during therapy using Transforming Growth Factor- $\beta 2$. A Transforming Growth Factor- $\beta 2$ enriched fraction prepared from bovine milk was shown to protect small intestinal epithelial cells against cell cycle specific chemotherapeutic agents by arresting the cells in GI-phase. Secondly, in a rat model for induced small intestinal damage, oral supplementation of rats exposed to methotrexate with the Transforming Growth Factor- $\beta 2$ enriched fraction significantly reduced the chemotherapy-associated weight loss and ileal villus atrophy by reducing cell proliferation in the normal stem cell population. Thus oral supplementation with a bovine milk fraction enriched for Transforming Growth Factor- $\beta 2$ attenuated the side effects of chemotherapy in the small intestine in rats. British Journal of Cancer (2002) 87, I I3 - I 8. doi: I 0.1038/sj.bjc.6600342 www.bjcancer.com (c) 2002 Cancer Research UK
\end{abstract}

Keywords: Transforming Growth Factor $\beta 2$; oral supplementation; chemotherapy-chemoprotection; GI-phase growth arrest

Anti-cancer chemotherapy and radiation treatment relies primarily on the high proliferation rate of tumour cells. Stem cells of the gastrointestinal tract are among the most rapidly proliferating cells in the body, and therefore also affected by this anti-tumour approach targeted towards proliferating cells. Entrocyte function in rats has been shown to be effected adversely by methotrexate (MTX) resulting in altered intestinal permeability (Taminiau et al, 1980) which has a counterpart in humans (Keefe et al, 1997; Parrilli et al, 1989). The several complications, i.e. vomiting, nausea and mucosal barrier injury (Sonis, 1998; Blijlevens et al, 2000) result from loss of integrity of the intestinal barrier which is a key element in preventing inappropriate uptake and transport of macromolecules, bacteria and enteric toxins. To date, there is still no validated method to treat the side effects of anti-cancer treatment.

Specific cell cycle arrest of rapid proliferating epithelial stem cells is a promising approach to protect the mucosa from the direct side effects of anti-cancer treatment. Transforming Growth Factor$\beta 3$ (TGF- $\beta 3$ ) has been shown to prolong or arrest the cell cycle of epithelial cells in the G1-phase thereby providing protection in vitro against cell-cycle specific chemotherapeutic agents that act predominantly in the S- or M-phase of the cell cycle (McCormack et al, 1997). Topical administration of recombinant human TGF- $\beta 3$ has also been shown to attenuate the oral mucositis induced in hamsters by 5 -Fluorouracil with a concomitant reduction in weight loss and shorter duration of oral mucositis (Sonis et al, 1997; Spij-

*Correspondence: L M'Rabet; E-mail: Laura.MRabet@Numico-Research.nl Received 18 September 200I; revised 14 February 2002; accepted 3 April 2002 kervet and Sonis, 1998). It has been suggested that this protection is mediated by the inhibition of proliferation of basal epithelial cells during exposure to chemotherapy. Positive results have been obtained in humans using mouthwashes containing recombinant TGF- $\beta 3$ (Wymenga et al, 1999), indicating a promising treatment against the oral complications of anti-cancer therapy. Administration of recombinant TGF- $\beta 3$ directly into the small intestine of mice had a protective effect during radiation (Potten et al, 1997) by reducing stem cell cycling (Booth et al, 2000). To our knowledge however, no study has been done investigating the potential protective effects of orally administrated TGF- $\beta 2$ originating from a natural source. We therefore set out to determine the efficacy in vitro and in vivo of TGF- $\beta 2$ in protecting intestinal epithelial cells from damage induced by methotrexate (MTX).

\section{MATERIALS AND METHODS}

\section{Cells}

The small intestine rat epithelial cell line (IEC-6) was obtained from ATCC (Rockville, MD, USA) and cultured at $37^{\circ} \mathrm{C}$ and $5 \%$ $\mathrm{CO}_{2}$ in Dulbecco's modified Eagle's medium adjusted to contain $1.5 \mathrm{~g} \mathrm{l}^{-1}$ sodium bicarbonate and $4.5 \mathrm{~g} \mathrm{l}^{-1}$ glucose and supplemented with $50000 \mathrm{IU}^{-1}$ penicillin, $50 \mathrm{mg} \mathrm{l}^{-1}$ streptomycin and $10 \%$ heat inactivated foetal calf serum (FCS) all obtained from Gibco BRL. Cells were used between passage 19 and 35 .

\section{TGF- $\beta 2$ enriched fraction}

TGF- $\beta 2$ enriched fraction was obtained from bovine milk by purification with cationic exchange chromatography (DMV 
international). The TGF- $\beta 2$ enriched fraction contained $750 \mu \mathrm{g} \mathrm{g}^{-1}$ TGF- $\beta$ protein consisting for $\sim 90 \%$ TGF- $\beta 2$ and $\sim 10 \%$ TGF- $\beta 1$. No detectable levels of TGF- $\beta 3$ could be measured by ELISA techniques. Forty-nine per cent of the TGF- $\beta$ in the fraction was unbound and active as measured in a bioassay.

\section{Proliferation assay}

IEC-6 cells were cultured for $72 \mathrm{~h}$ in a 96-well microtiter plate (Costar, Schiphol, The Netherlands) with a concentration range of $0.25-2.5 \mathrm{ng} \mathrm{ml}^{-1}$ of recombinant TGF- $\beta 3$ or TGF- $\beta 2$ in the enriched fraction. Sixteen hours before the end of the assay $10 \mu \mathrm{M}$ 5-bromo-2'-deoxyuridine (BrdU) was added to the wells, and the incorporation was visualised according to the manufacture protocol (Boehringer Mannheim), and measured at $450 \mathrm{~nm}$.

\section{Cell death/cell cycle arrest}

To establish the capacity of TGF- $\beta 2$ enriched fraction to arrest cells in growth, flowcytometry analyses were done. IEC-6 cells were cultured in a 6 well plate and incubated together with $2.5 \mu \mathrm{g} \mathrm{ml}^{-1}$ cytosine arabinoside (Ara-C, cytarabine; Sigma, Zwijndrecht, The Netherlands) for $48 \mathrm{~h}$ with or without TGF- $\beta 2$ enriched fraction $\left(2 \mathrm{ng} \mathrm{ml}^{-1}\right.$ of TGF- $\left.\beta 2\right)$ or $2 \mathrm{ng} \mathrm{ml}^{-1}$ recombinant TGF- $\beta 3$. The cells were then harvested and prepared for flowcytometry as described previously (Fraker et al, 1995). Briefly, cells were trypsinised, washed twice with PBS containing $0.1 \%$ EDTA (PBS-E) then fixed in $70 \%$ ethanol for $45 \mathrm{~min}$ at $-20^{\circ} \mathrm{C}$. Cellular DNA was labelled with propidium iodide by washing the cells twice with PBS-E and incubating them with PBS-E containing propidium iodide $\left(5 \mu \mathrm{g} \mathrm{ml}^{-1}\right)$ and RNA-se $\left(1 \mu \mathrm{g} \mathrm{ml}^{-1}\right)$ for $45 \mathrm{~min}$ in the dark. The cell preparations were analysed using a flowcytometer (Coulter, Mijdrecht, The Netherlands) and were separated into three populations according to their fluorescence intensity i.e. DNA content $\mathrm{N}=1$ represent cells in the G1-phase, $\mathrm{N}=2$ mitotic G2-phase and apoptotic cells contain $\mathrm{N}<1$ amount of DNA.

\section{In vitro cell viability assay}

IEC-6 cells were harvested in the exponential phase of growth, deposited in 96-well microtitration plates (Costar, Schiphol, The Netherlands) and cultured for $24 \mathrm{~h}$ with or without TGF- $\beta 2$ enriched fraction $\left(2 \mathrm{ng} \mathrm{ml}^{-1}\right.$ TGF- $\left.\beta 2\right)$. A concentration range of $0.05-0.13 \mu \mathrm{g} \mathrm{ml}^{-1}$ Cytosine Arabinoside (Ara-C) (Sigma, Zwijndrecht, The Netherlands) was subsequently added to the cells and incubated for $72 \mathrm{~h}$ at $37^{\circ} \mathrm{C}$ and $5 \% \mathrm{CO}_{2}$. The cells were then washed three times with PBS and incubated in normal medium for $48 \mathrm{~h}$ at $37^{\circ} \mathrm{C}$ and $5 \% \mathrm{CO}_{2}$. After $4 \mathrm{~h}$ incubation at $37^{\circ} \mathrm{C}$ with $50 \mu \mathrm{l}$ tetrazolium salt 2,3-bis[2-methoxy-4-nitro-5-[(sulphenylamino)carbonyl]-2H-tetrazolium-hydroxide] (XTT) solution as provided in the kit from Boehringer Mannheim, formation of the formazan dye by metabolically active cells was measured at $490 \mathrm{~nm}$. To establish that TGF- $\beta 2$ is the active compound in the fraction, neutralising monoclonal mouse anti-TGF- $\beta 2$ (Genzyme Diagnostics, Leuven, Belgium) was added at a concentration of $0.1 \mathrm{mg} \mathrm{ml}^{-1}$ for $1 \mathrm{~h}$, prior to testing in the cellular viability assay as described above.

\section{In vitro protease degradation assay}

In vivo protein degradation in the stomach was simulated by incubation of the TGF- $\beta 2$ fraction with a buffer containing $53 \mathrm{mmol} \mathrm{l}^{-1}$ $\mathrm{NaCl}, \quad 0.7 \mathrm{mmol} \mathrm{l}^{-1} \quad \mathrm{CaCl}_{2}, \quad 15 \mathrm{mmol} \mathrm{l}^{-1} \mathrm{KCl}, \quad 71 \mathrm{mmol} \mathrm{l}^{-1}$ $\mathrm{NaHCO}_{3}, 70 \mu \mathrm{g} \mathrm{ml}^{-1}$ pepsin from bovine pancreas (Sigma, Zwijndrecht, The Netherlands) and $70 \mu \mathrm{g} \mathrm{ml}^{-1}$ lipase (Sigma, Zwijndrecht, The Netherlands) at $\mathrm{pH} 3.0$ for $60 \mathrm{~min}$ at $37^{\circ} \mathrm{C}$. After incubation, the enzymes were inactivated by neutralising with $\mathrm{NaOH}$ to $\mathrm{pH} 7.0$, and stored at $-20^{\circ} \mathrm{C}$ until required for analysis. The remaining cytoprotective capacity of the fractions after protein degradation was tested in the cell viability assay as described before.

\section{MTX-animal model}

The animal experiments were approved by the Animal Care and Ethics Committee (DEC, The Netherlands) and were performed according to the UKCCCR 'Guidelines for the Welfare of Animals in Experimental Neoplasia' (1998). Eight-week old female Wag/Rij rats (Charles River, Wiga, Germany) with a weight average of $119.0 \pm 4.5 \mathrm{~g}$ were kept in pairs in conventional cages and in a $12 \mathrm{~h}$ reversed light/dark cycle, with free access to chow and water. All rats switched to a semi-synthetic diet (Hope-farms Woerden, The Netherlands) containing $1 \mathrm{mg} \mathrm{kg}^{-1}$ folic acid 7 days before starting the experiments. At the same time they were trained to expect to be given a supplement twice daily at $0900 \mathrm{~h}$ and $1600 \mathrm{~h}$ using a placebo containing $2.5 \%$ casein, $2.5 \%$ sucrose and strawberry vanilla flavour dissolved in water, which was added in addition to normal chow. Placebo and semi-synthetic diet were given to the animals until the end of the experiment. Supplementation of TGF- $\beta 2$ enriched fraction ( $5 \mu \mathrm{g}$ TGF- $\beta 2 /$ rat/day) was started on day -1 until day 1 . Two groups of rats ( $n=4$ per group) supplemented with placebo or the TGF- $\beta 2$ enriched fraction were injected i.v. on day 0 with $20 \mathrm{mg} \mathrm{kg}^{-1}$ body weight MTX (Ledertrexate SP Forte, AHP Pharma Hoofddorp, The Netherlands), followed by a second MTX injection of $10 \mathrm{mg} \mathrm{kg}^{-1}$ body weight $24 \mathrm{~h}$ later. Two groups of control animals ( $n=4$ per group) were injected with a similar volume of $7 \%$ saline solution and supplemented with either placebo or the TGF- $\beta 2$ enriched fraction. Body weight was monitored daily. In a pilot experiment (data not shown) it was found that maximal intestinal damage occurred on day 4, thus small intestine of each animal was collected subsequently at this time thereafter. Rats were injected with $50 \mathrm{mg} \mathrm{kg}^{-1}$ body weight BrdU i.p. $16 \mathrm{~h}$ before tissue collection to determine the effects on cellular proliferation and to establish the effect of the TGF- $\beta 2$ enriched fraction on intestinal epithelial cell proliferation two additional groups $(n=4)$ of animals were scarified $16 \mathrm{~h}$ after the last supplementation with the TGF- $\beta 2$ enriched fraction. Animals were killed under sedation and segments of the small intestine were removed for immunohistological staining and morphological examination. All segments were carefully rinsed once with cold PBS and fixed in 4\% paraformaldehyde at $\mathrm{pH} 7.4$ (Sigma, Zwijndrecht, The Netherlands) for $16 \mathrm{~h}$, dehydrated and embedded in paraffin.

\section{Immunohistology}

To examine morphological damage in the small intestine, $5 \mu \mathrm{m}$ sections were cut transversely to visualise the entire villus, subsequently rehydrated and stained with $1 \mathrm{mg} \mathrm{ml}^{-1}$ Haematoxylin (Sigma, Zwijndrecht, The Netherlands) and $10 \mathrm{mg} \mathrm{ml}^{-1}$ Eosin (Sigma, Zwijndrecht, The Netherlands). BrdU incorporation was detected using $0.5 \mu \mathrm{g} \mathrm{ml}^{-1}$ mouse monoclonal anti-BrdU (Boehringer Mannheim) followed by incubation with $1.5 \mu \mathrm{g} \mathrm{ml}^{-1}$ antimouse IgG (Vector Laboratories), which was visualised after thorough washings with PBS using ABC-complex (Vector Laboratories) and 3,3'-diaminobenzidine tablets dissolved in $\mathrm{H}_{2} \mathrm{O}$ (Sigma, Zwijndrecht, The Netherlands). Villus lengths, crypt depths and BrdUincorporation were measured with an image analysis program (Zeiss KS300). At leased 15 cross-sections per rat were analysed blindly by two independent researchers.

\section{Statistical analysis}

The Student two sided $t$-test was used to analyse cellular viability (expressed as a per cent of control) between cell cultures treated with chemotherapeutic agents and untreated control cultures, villus height 
and crypt depth measurements $(\mathrm{mm})$ and body weight (expressed as per cent of day 0 control) between the groups of animals supplemented with TGF- $\beta 2$ enriched fraction and those that were not. $P$ values $<0.05$ were considered statistically significant.

\section{RESULTS}

\section{The proliferation inhibition capacity of the TGF- $\beta 2$ enriched fraction}

A dose dependent proliferation inhibition up to $56 \pm 5 \%$ was seen when IEC-6 cells were incubated with $2.0 \mathrm{ng} \mathrm{ml}^{-1}$ TGF- $\beta 2$ in the enriched fraction. The in vitro proliferation inhibition capacity of the TGF- $\beta 2$ enriched fraction is comparable to equal concentrations of recombinant TGF- $\beta 3$ (Figure 1A). When IEC-6 cells were incubated with recombinant TGF- $\beta 3$ a decrease of $17.2 \%$ of the proliferating cells was seen in the flowcytometry analysis (Figure $1 B)$, which resulted in an increase in the G1-phase population. A comparable shift of $16.4 \%$ from proliferating cells to the G1-phase was seen with the TGF- $\beta 2$ enriched fraction. These results indicated that proliferation of the IEC- 6 cells is inhibited by the TGF- $\beta 2$ enriched fraction, due to growth arrest in the G1-phase.
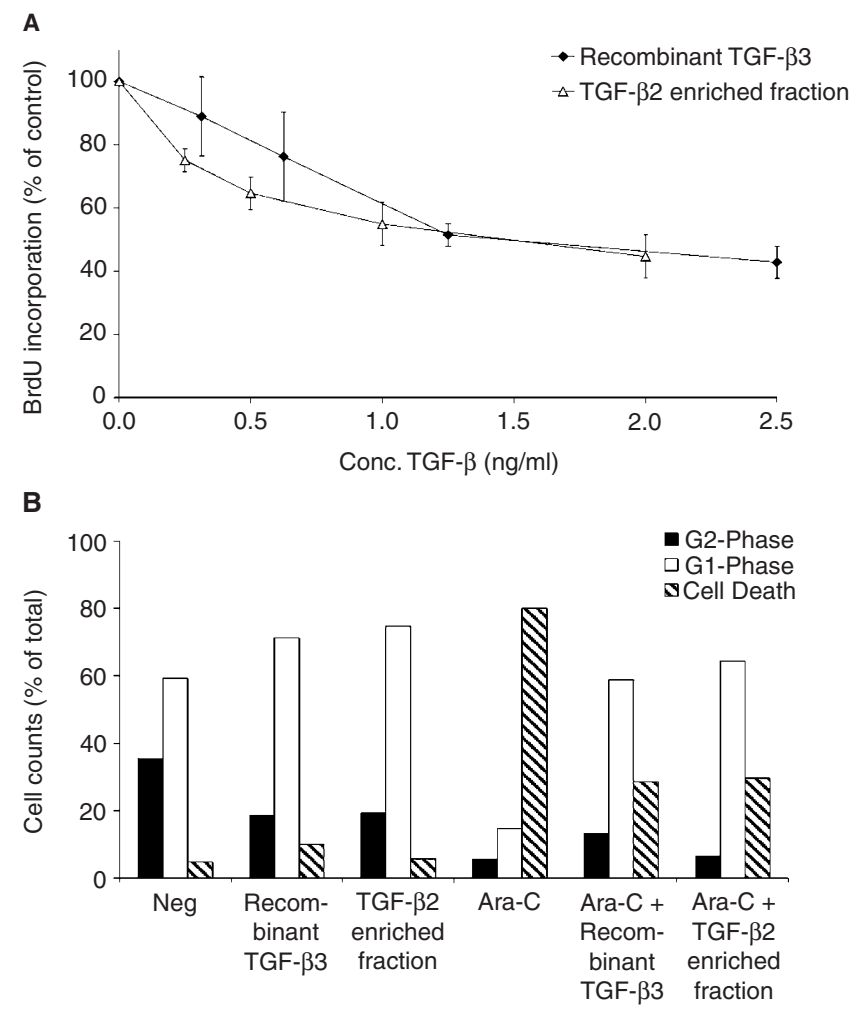

Figure I (A,B) TGF- $\beta 2$ enriched fraction and recombinant TGF- $\beta 3$ comparably inhibit proliferation and protect cells against Ara-C induced toxicity by induction of $\mathrm{GI}$-phase arrest. In Figure IA, BrdU incorporation into IEC-6 cells incubated for $48 \mathrm{~h}$ with a concentration range of recombinant TGF- $\beta 3$ (closed triangles) or the TGF- $\beta 2$ enriched fraction (open triangles) is shown. The data represent mean \pm s.d. of three independent experiments. In Figure IB, GI-phase arrest is detected by flowcytometryanalysis of propidium iodide labelled IEC-6 cells incubated with recombinant TGF- $\beta 3$ or the TGF- $\beta 2$ enriched fraction in the presence or absence of AraC. A total of 10000 cells were counted and divided into three sections, of which GI-phase represents cells with $\mathrm{N}$ amount of DNA, G2-phase represents the cells in proliferating phase i.e. containing N2 amount of DNA and the remaining dying cells (amount $<N$ ).

\section{Protective effect of TGF- $\beta 2$ enriched fraction on cell cycle-specific drug-induced damage}

An Ara-C dependent increase was seen in the fraction of apopotic cells on flowcytometry (Figure 1B) and a concentration dependent decline was seen in the cellular viability measured using XTT reagent (Figure $2 \mathrm{~A}$ ). In both assays inhibition of the toxic effect was seen when cells were incubated with TGF- $\beta 2$ enriched fraction in comparable efficiency as recombinant TGF- $\beta 3$. The IC50 for with Ara-C is $0.07 \mu \mathrm{g} \mathrm{ml}^{-1}$ in the absence of TGF- $\beta 2$ enriched fraction, whereas treatment in presence of the TGF- $\beta 2$ enriched fraction gave a six-fold higher IC-50 value $\left(0.43 \mu \mathrm{g} \mathrm{ml}^{-1}\right)$ indicating a higher cell survival. Even with high concentrations of Ara-C $\left(2.5 \mu \mathrm{g} \mathrm{ml}^{-1}\right), 30 \%$ of the cells remained viable when simultaneously incubated with the TGF- $\beta 2$ enriched fraction. Incubation with TGF- $\beta 2$ enriched fraction also showed a diminished reduction in cell viability of $28 \pm 7 \%$ when IEC- 6 cells were incubated with MTX, yet another cell cycle specific drug (Figure 2B).

The bovine milk fraction although enriched for TGF- $\beta 2$, might still contain other active proteins. The cytoprotective effect of the TGF- $\beta 2$ enriched fraction was completely blocked by pre-incubation of the fraction with a specific monoclonal anti-TGF- $\beta 2$ antibody. There was as little as $1 \%$ difference seen between the cells incubated with TGF- $\beta 2$ enriched fraction which was neutralised for TGF- $\beta 2$ and the cells treated with high doses of Ara-C alone (see Figure 2A).
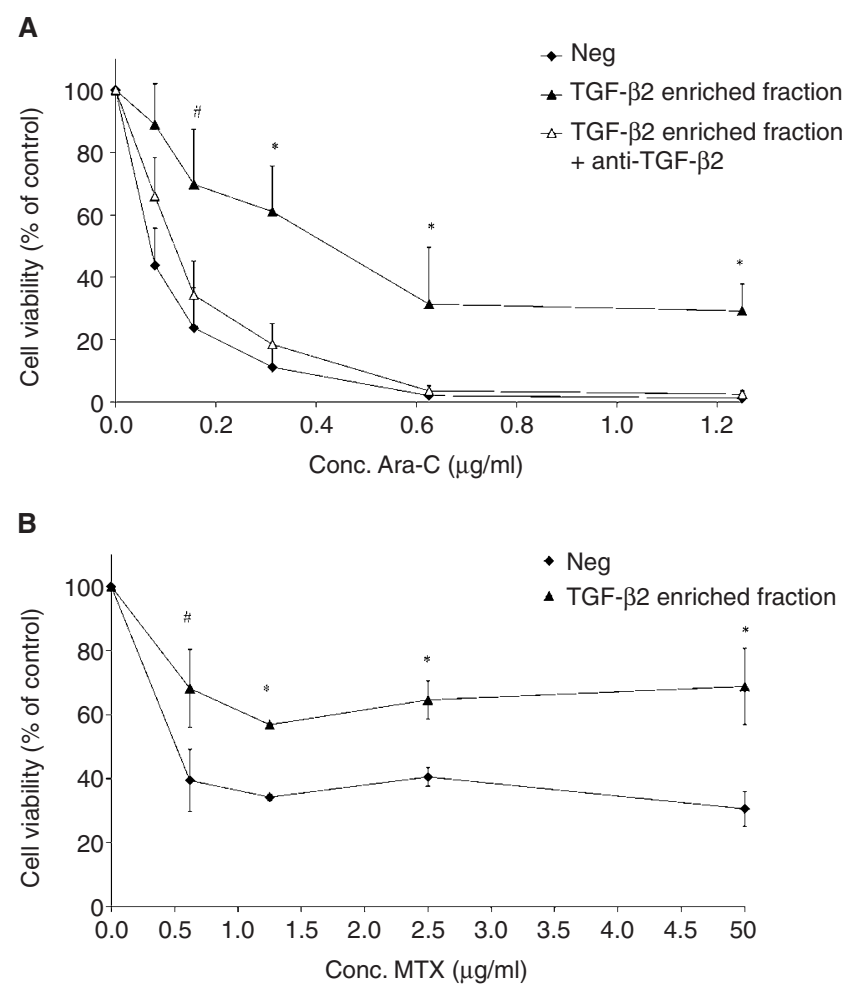

Figure 2 (A,B) Epithelial cells are protected against cell cycle specific drug, due to TGF- $\beta 2$ present in TGF- $\beta 2$ enriched fraction. Cell viability of IEC-6 cells after treatment with a concentration range of Ara-C (A) or MTX (B), incubated with (closed triangle) or without (closed square) TGF- $\beta 2$ enriched fraction is shown. The open triangles (A) show cells, which were incubated with TGF- $\beta 2$ enriched fraction after blocking of TGF- $\beta 2$ activity by pre-incubation with anti-TGF- $\beta 2$ antibodies. Mean \pm s.d. of three individual experiments is shown. Statistical differences between viability of cells incubated with TGF- $\beta 2$ enriched fraction after depletion for TGF- $\beta 2$ and control or TGF- $\beta 2$ alone are indicated with \# $(P<0.05)$ or $*(P<0.01)$. 
Since the use of TGF- $\beta 2$ enriched fraction in enteral nutrition was examined, in an in vitro protease degradation (as described in Materials and Methods), the effect of intestinal transit and degradation was evaluated. The remaining protective capacity of TGF- $\beta 2$ enriched fraction against Ara-C induced toxicity was tested on the IEC-6 cells after in vitro degradation with or without the presence of casein. Without the presence of casein, the protective effect of TGF- $\beta 2$ enriched fraction was indeed decreased after in vitro degradation to $3-4 \%$ and was totally diminished at higher concentrations of Ara-C (Figure 3). Within the presence of casein however, the protective effect of TGF- $\beta 2$ enriched fraction remained intact after the in vitro degradation, as it resulted in $21 \pm 3 \%$ cell viability left after exposure to the high concentrations of Ara-C.

\section{Protective effects of TGF- $\beta 2$ enriched fraction in vivo}

Throughout the entire small intestine MTX caused a shortening of villus length, to a minimum of $0.2 \mathrm{~mm}$ was seen due to MTX toxicity (Figure $4 \mathrm{~A})$. In the duodenum the villus length was reduced for $>50 \%$, in the jejunum for $\sim 40 \%$ and in the ileum a reduction of $\sim 25 \%$ was detected. Supplementation with TGF- $\beta 2$ enriched fraction resulted in restoration of villus length throughout the small intestine, and reached significance $(P<0.05)$ in the ileum. Villus length was reduced to $0.20 \pm 0.010 \mathrm{~mm}$ in the MTX treated group and restored to $0.27 \pm 0.009 \mathrm{~mm}$ in the rats supplemented with TGF- $\beta 2$ enriched fraction, which equals the villus length in the control rats $(0.27 \pm 0.006 \mathrm{~mm})$. However no significant restoration of villus atrophy seen after MTX treatment could be detected in the duodenum or jejunum. Equal protective capacities of the TGF- $\beta 2$ enriched fraction were found in a second set of experiments (data not shown). There was no effect seen on villus length in control rats supplemented with TGF- $\beta 2$ enriched fraction (Figure 4A). The effect of MTX on the crypt depths is shown in Figure 4B. No significant effect of the TGF- $\beta 2$ enriched fraction supplementation could be detected in the crypt depth measurements. The proliferation inhibition capacity of TGF- $\beta 2$ enriched fraction in vivo was estimated using $\mathrm{BrdU}$ incorporation during the $16 \mathrm{~h}$ after the last supplementation. The BrdU length was measured starting from the lowest BrdU positive crypt cell until the highest BrdU positive cell migrated upon the villus axes. As can been seen in Figure $4 \mathrm{C}$ a significant $(P<0.05)$ inhibition of proliferation could be detected in the ileum of rats supplemented with the TGF- $\beta 2$ enriched fraction compared to the control group.

All the control animals not receiving MTX, showed a steady growth, which was unaffected by the supplementation of TGF- $\beta 2$

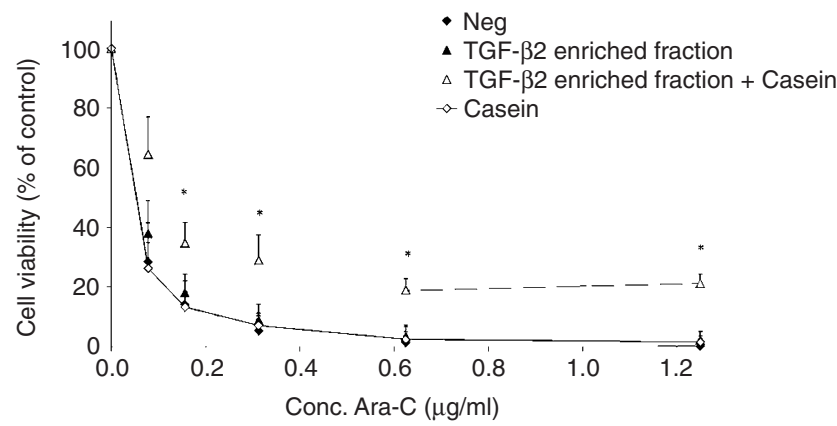

Figure 3 Diminished degradation of TGF- $\beta 2$ due to the presence of casein. Cell viability of IEC-6 cells after treatment with a concentration range of Ara-C, of which the triangles represent treatment with TGF- $\beta 2$ enriched fraction in an in vitro degradation assay, with (open) or without (closed) casein present during the degradation. The controls with (open), or without (closed) casein during the in vitro degradation assay, are represented by squares. Mean + s.d. of three separate experiments are shown. *Indicates significant differences with the negative control group $(P<0.0 \mathrm{I})$. enriched fraction (Figure 5). The rats however treated with MTX showed a reduction in body weight already after the first MTX injection, resulting in difference of $15 \pm 2 \%$ with the control rats at day 4. Supplementation with TGF- $\beta 2$ enriched fraction during MTX-treatment showed significantly less reduction in body weight than animals receiving placebo. The average body weight loss of the
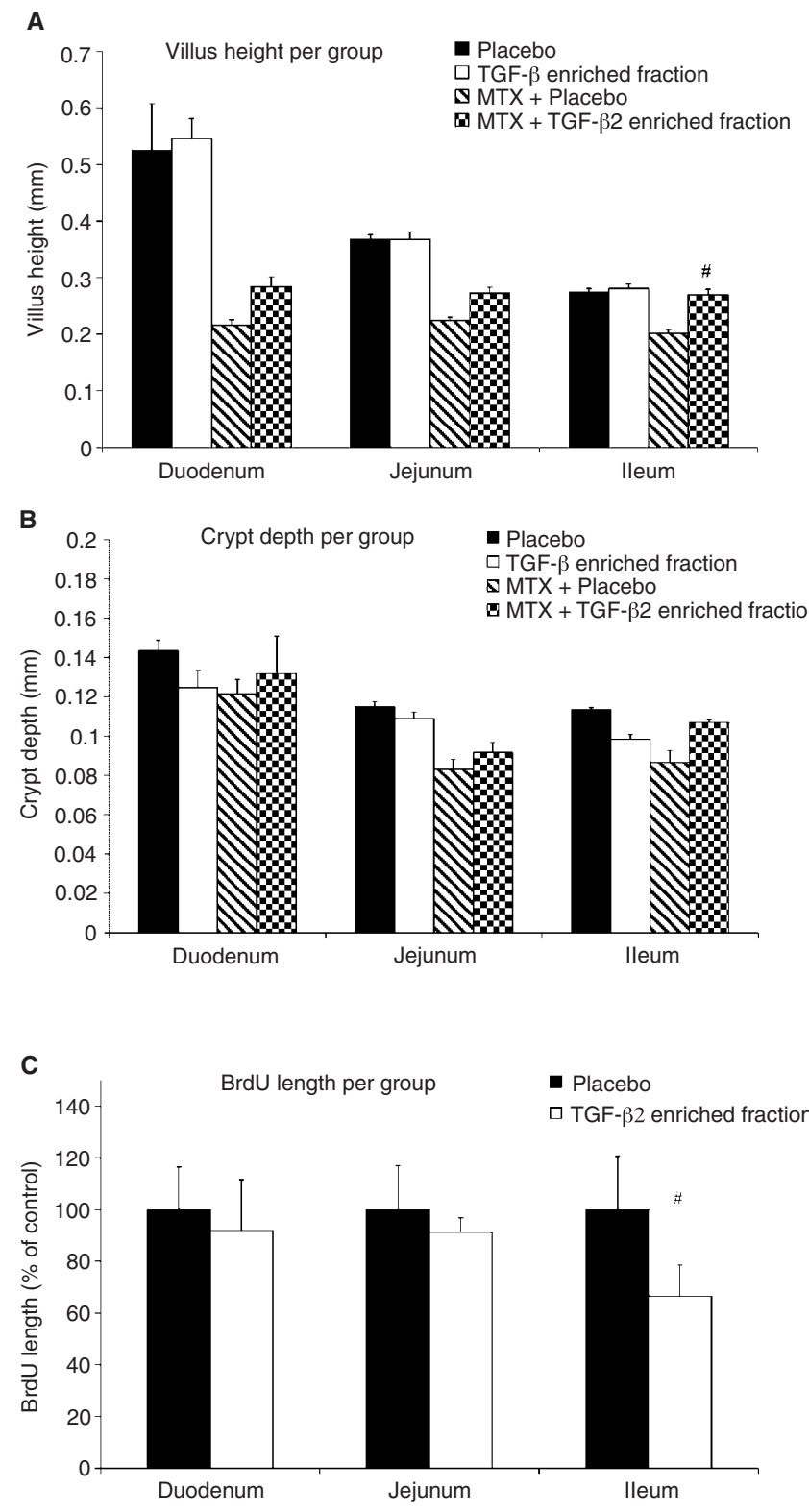

Figure $4(\mathbf{A}, \mathbf{B}, \mathbf{C})$ Supplementation of TGF- $\beta 2$ enriched fraction reduced MTX induced villus atrophy due to stem cell proliferation inhibition. Villus length $(\mathbf{A})$ and crypt depths $(\mathbf{B})$ were measured from different regions in the small intestine at day 4 ( $n=4$ per group) from rats receiving either placebo (closed bars) or the TGF- $\beta 2$ enriched fraction (open bars). Statistical differences between the MTX control group only receiving placebo (hatched bars) or TGF- $\beta 2$ enriched fraction (squared bars) are indicated with $\#(P<0.05)$. At least 60 microscopical measurements were made per animal, at a magnification of $10 \times$ per rat. Bars show mean \pm s.d. for three rats per group. In Figure $(\mathbf{C})$, BrdU incorporation is shown as length in per cent of control, measuring from the lowest BrdU positive crypt cell until the highest BrdU positive cell upon the villus axis. Lengths were measured in different regions of the small intestine at day two from four rats per group receiving placebo (closed bars) or TGF- $\beta 2$ enriched fraction (open bars). Statistical differences are indicated with $\#(P<0.05)$. 


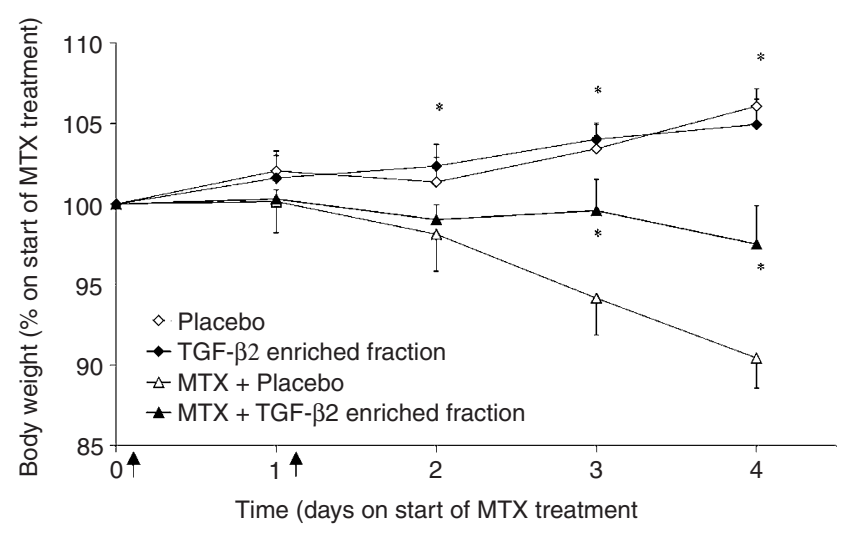

Figure 5 Weight loss due to MTX toxicity is reduced by supplementation of TGF- $\beta 2$ enriched fraction. Effect of MTX on the weight of rats is shown as per cent of weight on day 0 (mean \pm s.d.). The arrows located on the $\mathrm{X}$-axis indicate the two MTX injections. Two groups of rats treated with or without MTX are shown in triangles and squares respectively, in which the closed symbols represent groups supplemented with TGF- $\beta 2$ enriched fraction. *Indicates significant differences between the MTX treated group receiving placebo and the other groups. $(P<0.0 \mathrm{I})$.

supplemented rats was only $\sim 3 \%$, whereas rats receiving only MTX lost $\sim 10 \%$ of their body weight.

\section{DISCUSSION}

The small intestine maintains its function due to solid regulation between epithelial cell proliferation, differentiation, and cell death at the tip of the villus. During cytostatic chemotherapy, this balance is disrupted by early cell death of the dividing stem cells located in the crypt area. The present study shows that reducing epithelial stem cell proliferation with TGF- $\beta 2$ enriched milk fraction from bovine origin protects the small intestinal epithelial cell in vitro as well as in vivo from this premature death. It was shown that the proliferation inhibition and cytoprotection of the TGF- $\beta 2$ enriched fraction is as effective as recombinant TGF- $\beta 3$. Furthermore immuno-neutralisation of TGF- $\beta 2$ from the enriched fraction proved that it is the TGF- $\beta 2$ in the fraction that protects the cells from cell-cycle specific drug-induced cell death, i.e. Ara-C (Figure 2A) and MTX (Figure 2B) in vitro.

The protective mechanisms of growth factors used in animal models of mucosal barrier injury are likely to be multifactoral. The benefit of pre-treatment with IL-11 and KGF has been shown to modulate chemotherapy- or radiation-induced intestinal epithelial injury (Potten, 1995, 1996; Farrell et al, 1998). The mechanism whereby by IL-11 protects remains to be elucidated, but the protection mediated by TGF- $\beta 3$ and KGF appears to be due to a reduction in stem cell proliferation (Booth et al, 2000; Potten et $a l, 2001)$. It is known that TGF- $\beta 3$ reversibly arrests cell growth in the G1-phase (Ko et al, 1998; Warner et al, 1999) which was confirmed for the TGF- $\beta 2$ enriched fraction (Figure 1B). Reduced proliferation of stem cells in vivo could also be detected after supplementation of TGF- $\beta 2$ enriched fraction showing limited BrdU incorporation (Figure 4C). The significant protection of TGF- $\beta 2$ enriched fraction seen on villus atrophy was limited to the ileum, which was also the region where significant reduction of proliferation was found which indicates that protection is brought about by reduced stem cell proliferation. Cell cycle specific chemotherapeutic agents like Ara-C and MTX, inhibit specific enzymes, leading to inhibition of DNA replication with $S$ phase specificity. These processes are reduced in cells with arrested growth in the G1-phase by TGF- $\beta 2$. In accordance with our results epithelial cell proliferation stimulation during chemotherapy treatment with IGF-1 is not favourable (Howarth et al, 1998). IGF-1 given after chemotherapy however resulted in an improved regeneration of small intestinal damage (Taylor et al, 2001). A study done by Howarth et al (1996) using a growth factor enriched milk fraction, which offered a slight protection against MTX induced damage in vivo. TGF- $\beta 2$ mediated G1-phase cell-cycle arrest could not explain this protective effect since the fraction in question actually stimulated the growth of epithelial cells in vitro rather than arresting it.

The length of the villus of the duodenum is twice as long as that of the ileum which might reflect a higher proliferating rate of the epithelial cells, or the presence of more crypts containing stem cells per villi in the duodenum than in the ileum. Equal damage to the epithelial cells after exposure to MTX might explain why villus length was reduced two-fold in the duodenum compared to the ileum 4 days after MTX treatment. Strangely, however, unlike what was seen in the ileum, villus length in the duodenum did not return to its normal length after supplementation with the TGF$\beta 2$ enriched fraction. Differences in TGF- $\beta 2$ induced proliferation inhibition efficiency might be related to binding with casein, rendering it less free and therefore less active at the beginning of the small intestine. This difference in villus restoration could also reflect diversity in TGF- $\beta$ receptor expression throughout the small intestine. TGF- $\beta 3$ and TGF- $\beta 1$ show preferential binding to the RI and RII signalling complex, whereas TGF- $\beta 2$ requires RIII for presentation to the RI/RII complex in order to initiate the cascade of events leading to proliferation inhibition (Moustakas et al, 1993; Henis et al, 1994). The expression of TGF- $\beta$ receptors on epithelia in the small intestine is currently under investigation. Although a significant restoration of the villus atrophy could only be detected in the ileum, the weight of animals receiving TGF- $\beta 2$ enriched fraction did not show the same reduction as seen in MTX treated animals receiving placebo which indicates that supplementation of TGF- $\beta 2$ enriched fraction attenuates small intestinal function loss induced by MTX.

Safety and tolerability studies are required before oral supplementation of TGF- $\beta 2$ enriched fraction can be used clinically. In addition, supplementation of any product reducing side effects of anti-tumour treatment should not influence the treatment on cancer cells negatively. A phase I study has already been conducted to determine the safety and tolerability of recombinant TGF- $\beta 3$ mouthwashes for prevention of chemotherapy induced oral mucositis (Wymenga et al, 1999). In this study neither systemic absorption nor development of TGF- $\beta 3$ antibodies were observed. It should be considered however, that the mouthwashes were not ingested, which is essential for TGF- $\beta 2$ which is intended for the treatment of mucosal barrier injury throughout the whole gastrointestinal tract. On the other hand, a relative low dose of TGF- $\beta 2$ could be used, since systemic uptake of TGF- $\beta 2$ is not required to protect the intestinal epithelial stem cells. There is a strong correlation between progressive malignancy and loss in sensitivity towards the negative regulation of cellular proliferation TGF- $\beta$ in tumour cells, which is often due to mutational inactivation or decreased TGF- $\beta$ receptor function (de Caestecker et al, 2000; Kim et al, 2000). In addition tumour cells often escape from the anti-proliferative effects of TGF- $\beta$ by mutation or disregulated expression of components in its signalling pathway (Yanagisawa et al, 2000). These publications suggest that TGF- $\beta 2$ could be given safely during anti-tumour therapy. In conclusion, the present results indicate that oral supplementation of bovine TGF- $\beta 2$ enriched milk fraction might prove useful in ameliorating the complications of anti-cancer therapy in humans with TGF- $\beta 2$ unresponsive tumour cells.

\section{ACKNOWLEDGEMENTS}

The authors would like to acknowledge DMV-international for their generous gift of the TGF- $\beta 2$ enriched fraction. 


\section{REFERENCES}

United Kingdom Co-ordinating Committee on Cancer Research (UKCCCR) (1998) Guidelines for the Welfare of Animals in Experimental Neoplasia (Second Edition). Br J Cancer 77: 1-10

Blijlevens NMA, Donnelly JP, De Pauw BE (2000) Mucosal barrier injury: biology, pathology, clinical counterparts and consequences of intensive treatment for haematological malignancy: an overview. Bone Marrow Transplant 25: $1269-1278$

Booth D, Haley JD, Bruskin AM, Potten CS (2000) Transforming growth factor-B3 protects murine small intestinal crypt stem cells and animal survival after irradiation, possibly by reducing stem-cell cycling. Int $J$ Cancer 86: $53-59$

de Caestecker MP, Piek E, Roberts AB (2000) Role of transforming growth factor-beta signaling in cancer. J Natl Cancer Inst 92: 1388-1402

Farrell CL, Bready JV, Rex KL, Chen JN, DiPalma CR, Whitcomb KL, Yin S, Hill DC, Wiemann B, Starnes CO, Havill AM, Lu ZN, Aukerman SL, Pierce GF, Thomason A, Potten CS, Ulich TR, Lacey DL (1998) Keratinocyte growth factor protects mice from chemotherapy and radiationinduced gastrointestinal injury and mortality. Cancer Res 58: $933-939$

Fraker PJ, King LE, Lill-Elghanian D, Telford WG (1995) Quantification of apoptotic events in pure and heterogeneous populations of cells using the flow cytometer. Methods Cell Biol 46: 57-76

Henis YI, Moustakas A, Lin HY, Lodish HF (1994) The types II and III transforming growth factor-beta receptors form homo-oligomers. J Cell Biol 126: $139-154$

Howarth GS, Cool JC, Bourne AJ, Ballard FJ, Read LC (1998) Insulin-like growth factor-I (IGF-I) stimulates regrowth of the damaged intestine in rats, when administered following, but not concurrent with, methotrexate. Growth Factors 15: 279-292

Howarth GS, Francis GL, Cool JC, Xu X, Byard RW, Read LC (1996) Milk growth factors enriched from cheese whey ameliorate intestinal damage by methotrexate when administered orally to rats. J Nutr 126: 2519-2530

Keefe DM, Cummins AG, Dale BM, Kotasek D, Robb TA, Sage RE (1997) Effect of high-dose chemotherapy on intestinal permeability in humans. Clin Sci (Colch) 92: 385-389

Kim SJ, Im YH, Markowitz SD, Bang YJ (2000) Molecular mechanisms of inactivation of TGF-beta receptors during carcinogenesis. Cytokine Growth Factor Rev 11: 159-168

Ko TC, Yu W, Sakai T, Sheng H, Shao J, Beauchamp RD, Thompson EA (1998) TGF-betal effects on proliferation of rat intestinal epithelial cells are due to inhibition of cyclin D1 expression. Oncogene 16: 3445-3454

McCormack ES, Borzillo GV, Ambrosino C, Mak G, Hamablet L, Qu GY, Haley JD (1997) Transforming growth factor-beta3 protection of epithelial cells from cycle-selective chemotherapy in vitro. Biochem Pharmacol 53: $1149-1159$

Moustakas A, Lin HY, Henis YI, Plamondon J, O'Connor-McCourt MD, Lodish HF (1993) The transforming growth factor beta receptors types I II, and III form hetero-oligomeric complexes in the presence of ligand. $J$ Biol Chem 268: 22215-22218
Parrilli G, Iaffaioli RV, Martorano M, Cuomo R, Tafuto S, Zampino MG Budillon G, Bianco AR (1989) Effects of anthracycline therapy on intestinal absorption in patients with advanced breast cancer. Cancer Res 49: 3689 3691

Potten CS (1995) Interleukin-11 protects the clonogenic stem cells in murine small-intestinal crypts from impairment of their reproductive capacity by radiation. Int J Cancer 62: 356-361

Potten CS (1996) Protection of the small intestinal clonogenic stem cells from radiation-induced damage by pretreatment with interleukin 11 also increases murine survival time. Stem Cells 14: 452-459

Potten CS, Booth D, Haley JD (1997) Pretreatment with transforming growth factor beta-3 protects small intestinal stem cells against radiation damage in vivo. $\mathrm{Br} J$ Cancer 75: $1454-1459$

Potten CS, O'Shea JA, Farrell CL, Rex K, Booth C (2001) The effects of repeated doses of keratinocyte growth factor on cell proliferation in the cellular hierarchy of the crypts of the murine small intestine. Cell Growth Differ 12: $265-275$

Sonis ST (1998) Mucositis as a biological process: a new hypothesis for the development of chemotherapy-induced stomatotoxicity. Oral Oncol 34: $39-43$

Sonis ST, Van Vugt AG, Brien JP, Muska AD, Bruskin AM, Rose A, Haley JD (1997) Transforming growth factor-beta 3 mediated modulation of cell cycling and attenuation of 5-fluorouracil induced oral mucositis. Oral Oncol 33: $47-54$

Spijkervet FK, Sonis ST (1998) New frontiers in the management of chemotherapy-induced mucositis. Curr Opin Oncol 10(Suppl 1): S23 - S27

Taminiau JA, Gall DG, Hamilton JR (1980) Response of the rat small-intestine epithelium to methotrexate. Gut 21: $486-492$

Taylor VL, Goddard C, Read LC (2001) A milk growth factor extract reduces chemotherapeutic drug toxicity in epithelial cells in vitro. In Vitro Cell Dev Biol Anim 37: 310-318

Warner BJ, Blain SW, Seoane J, Massague J (1999) Myc downregulation by transforming growth factor beta required for activation of the p15(Ink4b) G(1) arrest pathway. Mol Cell Biol 19: 5913-5922

Wymenga ANM, van der Graaf WTA, Hofstra LS, Spijkervet FKL, Timens W, Timmer Bosscha H, Sluiter WJ, van Buuren A, Mulder NH, de Vries EGE (1999) Phase I study of transforming growth factor-beta 3 mouthwashes for prevention of chemotherapy-induced mucositis. Clin Cancer Res Jun 5: $1363-1368$

Yanagisawa K, Uchida K, Nagatake M, Masuda A, Sugiyama M, Saito T, Yamaki K, Takahashi T, Osada H (2000) Heterogeneities in the biological and biochemical functions of Smad2 and Smad4 mutants naturally occurring in human lung cancers. Oncogene 19: 2305-2311 